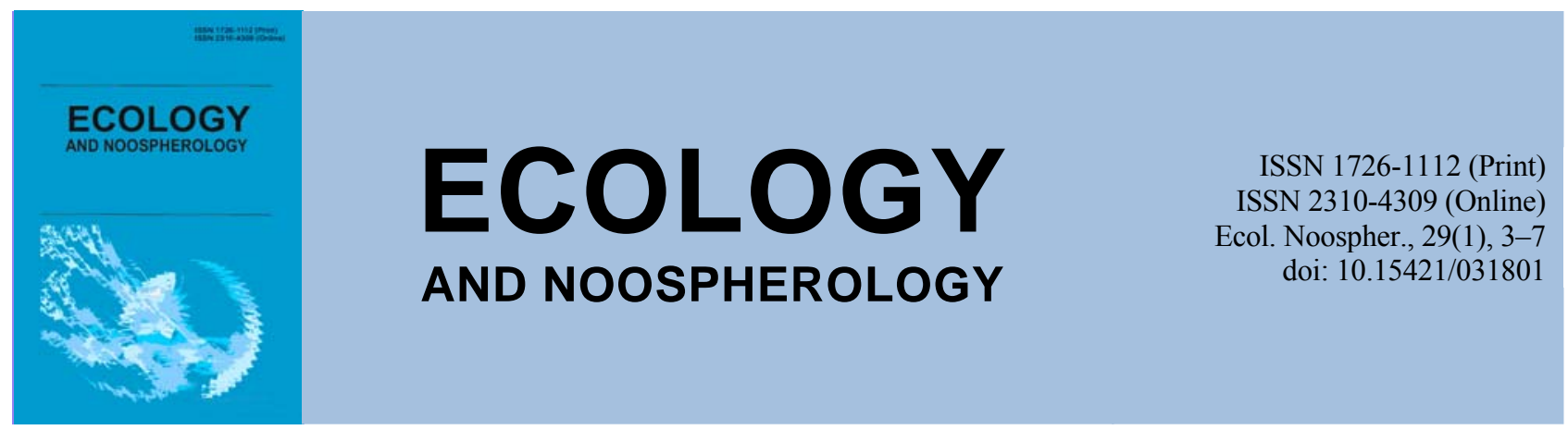

\title{
Dynamics of protection antioxidant system of representatives of Amelanchier Medik. genus during ontogenesis under Steppe Pridniprov'e conditions
}

\author{
Y. V. Lykholat, N. O. Khromykh, L. V. Shupranova, \\ T. V. Legostaeva, T. Y. Lykholat, A. V. Onopa
}

Oles Honchar Dnipro National University, Dnipro, Ukraine

Article info

Received 22.05.2018

Received in revised form 03.06 .2018

Accepted 10.06.2018

Oles Honchar Dnipro National University, Gagarin Ave., 72, Dnipro, 49010, Ukraine.

Tel.: +38-097-408-25-02

E-mail: kamelina502@ukr.net
Lykholat, Y. V., Khromykh, N. O., Shupranova, L. V., Legostaeva, T. V., Lykholat, T. Y., \& Onopa, A. V. (2018). Dynamics of protection antioxidant system of representatives of Amelanchier Medik. genus during ontogenesis under Steppe Pridniprov'e conditions. Ecology and Noospherology, 29(1), 3-7. doi:10.15421/031801

Antioxidant reaction in leaves of the representatives of Amelanchier Medik. genus introduced in Steppe Pridniprov'e during vegetative period is studied. Activity of bensidin-peroxidase (BPOD), guaiacol-peroxidase (GPOD) and catalase (CAT) in leaves of four kinds Amelanchier Medik is analysed. Specific features of dynamics of enzymes activity in leaves of representatives of Amelanchier Medik. genus are defined according to phases of seasonal development and in reply to action of hydrothermal stress. On the basis of the received results the wide range of interspecific variability of enzymes activity in leaves of Amelanchier kinds, introduced in new conditions of existance is shown. The studied kinds were characterised by high activity BPOD in all vegetative season. The greatest activity in leaves of all kinds was shown in a phase of secondary growth, in the most adverse hydrothermal mode that testified to passage of adaptive processes in plants. It is established, that unlike $A$. ovalis in which leaves level of activity BPOD was equal enough, other kinds in process of ontogenesis have shown sharper differences in activity of enzyme. The difference was essential, especially at $A$. canadensis in which leaves in May and June sharp falling of activity in 4,0 and 2,9 times accordingly in comparison with April was noticed, and in July and August - sharp increase that testified to a stressful condition of plants. The opposite tendency is found out in dynamics of activity GPOD i CAT. In the beginning phases of active growth (April) at all kinds the highest activity of enzymes, but, since May and till the end of the supervision period was observed, activity sharply went down at all kinds Amelanchier. Essential activation GPOD in a phase of active growth can be connected with processes of lignification to an greater degree, rather than with protection against oxidative stress. Thus in leaves of $A$. ovalis and A. canadensis higher activity gvaiacol-peroxidase, than at A. spicata and A. florida was observed. Small increase of activity was observed in June and to an greater measure in three kinds: A. ovalis, A. florida i A. spicata. In leaves of A. canadensis activity increase was marked in August in comparison with the period from May till July. The analysis of dynamics of catalase activity in leaves of representatives Amelanchier Medik. has shown similitude as well as at gvaiacol-peroxidase: the highest level was observed in April, and further there was an essential recession of enzyme activity. Dynamics of catalase activity during vegetation has appeared the most similar at kinds of $A$. ovalis and $A$. canadensis. In leaves of A. florida unlike last kinds the small peak of activity in July was marked, and in August activity again went down on $21,8 \%$ in comparison with July. A. spicata has shown essential increase of activity CAT in August in comparison with July in 6,4 times. Thus, found out different directions of activity changes of oxidoreductases specify in participation antioxidant systems in realisation of different ways of adaptation of kinds-introducents of Amelanchier Medik. genus in ontogenesis process in the conditions of Pridneprov'e Steppe. Variability of enzymes activity level in leaves of Amelanchier Medik. in the course of vegetation means the adaptation to conditions of environment and as a whole displays adaptive ability of the investigated kinds at the expense of high antioxidant potential to counteract development of oxidative stress at action adverse of abiotic factors.

Keywords: introducents; Amelanchier Medik.; catalase; benzidine-peroxidase; gvaiacol- peroxidase 


\title{
Динаміка антиоксидантної системи захисту представників роду Amelanchier Medik. у процесі онтогенезу в умовах Степового Придніпров'я
}

\author{
Ю. В. Лихолат, Н. О. Хромих, Л. В. Шупранова, \\ Т. В. Легостаєва, Т.Ю.Лихолат, А. В. Онопа
}

Дніпровський національний університет імені Олеся Гончара, Дніпро, Украӥна

Вивчено антиоксидантну реакцію листків інтродукованих у Степове Придніпров'я представників роду Amelanchier Medik. протягом періоду вегетації в культурі Ботанічного саду ДНУ ім. О. Гончара. Листки чотирьох видів ірги (A. ovalis, A. spicata, A. canadensis, A. florida) аналізували на активність бензидин-пероксидази (BPOD), гваякол-пероксидази (GPOD) i каталази (САT). Визначено індивідуальні особливості динаміки активності ензимів у листках представників роду Amelanchier Medik. відповідно до фаз сезонного розвитку і у відповідь на дію гідротермічного стресу. На основі отриманих результатів показано широкий діапазон міжвидової варіабельності активності ферментів у листках видів ірги, індукованих умовами навколишнього середовища. Вивчені види характеризувалися високою активністю бензидин-пероксидази впродовж вегетаційного періоду. Найбільша активність у листках усіх видів проявлялась у фазу вторинного росту, у період найбільш несприятливого гідротермічного режиму, що свідчило про адаптивні процеси в рослин. Протилежну тенденцію виявлено в змінах активності GPOD і CAT. На початку фази активного росту (квітень) у всіх видів спостерігалась максимальна активація ферментів, але починаючи 3 травня і до кінця періоду спостережень активність різко знижувалась. Таким чином, виявлено різноспрямовані зміни активності оксидоредуктаз, що вказує на участь антиоксидантної системи в реалізації різних шляхів адаптації видів-інтродуцентів роду Amelanchier Medik. у процесі онтогенезу в умовах Степового Придніпров'я.

Ключові слова: інтродуценти; Amelanchier Medik.; каталаза; бензидин-пероксидаза; гваякол-пероксидаза

\section{Вступ}

Для збереження біологічного різноманіття i розширення спектру цінних сільськогосподарських рослин у степовій зоні України інтерес викликає інтродукція нетрадиційних плодових культур, серед яких представники роду Amelanchier Medik., що відрізняються швидким ростом, довговічністю, щорічним рясним плодоношенням, високими смаковими та лікувально-дієтичними якостями плодів. Крім того, вони $\epsilon$ декоративними, фітомеліоративними, медоносними та лікарськими рослинами (Andrienko, 2016; Kuklina et al., 2017).

Відомо 33 види ірги, що ростуть у помірному поясі Північної півкулі: Північній Америці, Північній Африці, Центральній та Південній Європі, Кавказі, Криму та Японії. Характерними для Північної Америки і Канади є $A$. canadensis, A. spicata, та A. florida, які інтродуковані в культуру Ботанічного саду ДНУ. A. ovalis є аборигенним видом для флори Свропи, Африки і Туреччини. Для флори України A. ovalis визначається як аборигенний вид для середньої гірської зони та скелястих ділянок Криму (Andrienko, 2016)

Види роду Amelanchier Medik. відносять до рослин із широким діапазоном толерантності до впливу екологічних чинників. По відношенню до вологи, температури, світла i грунту вони $\epsilon$ мезофітами, мезотермофітами, геліофітами i мезотронами відповідно (Andrienko, 2016). Серед видів ірги A. spicata та A. florida мають високу зимостійкість і здатні переносити морози нижче $-35-50{ }^{\circ} \mathrm{C}$. До видів із достатнім рівнем зимостійкості відносять $A$. canadensis i $A$. ovalis, які здатні витримувати морози до $-10{ }^{\circ} \mathrm{C}$ (Kuklina, 2007). Види ірги добре переносять посуху і можуть рости на піщаних ділянках, незважаючи на те, що вони $\epsilon$ мезофітами. В умовах степової зони України основним негативним чинником $є$ недостатня водозабезпеченість на фоні високих температур влітку і ранньою осінню, що обмежує успішність інтродукції рослин (Prisedsky et al., 2017).

В умовах культури Ботанічного саду ДНУ фізіологобіохімічна характеристика представників роду Amelanchier Medik. залишається майже не вивченою. Відомості про особливості системи захисту в різних органах видів ірги в умовах північної частини Степу України представлені лише в окремих роботах (Dolgova and Samojlova, 2010;
Kabar et al., 2016). У той же час виявлення значущих для видів різного географічного походження параметрів системи захисту в умовах впливу однакового комплексу факторів дозволить виділити ті якості рослинного організму, які найбільш важливі для його стійкості за впливу несприятливих чинників середовища.

Мета роботи - 3'ясувати особливості функціонування антиоксидантної системи в листках представників роду Amelanchier Medik. протягом онтогенезу в умовах інтродукції.

\section{Матеріали та методи досліджень}

Робота проводилась на базі колекційного фонду Ботанічного саду Дніпровського національного університету імені Олеся Гончара м. Дніпра (48026'14'” N, 35002'35” Е) в 2017 р. Об'єктами дослідження стали чотири види роду Amelanchier Medik.: ірга колосиста (A. spicata), ірга овальна (A. ovalis), ірга багатоквіткова (A. florida) та ірга канадська (A. canadensis). Листки видів ірги відбирали протягом вегетаційного періоду у квітні, травні, червні, липні і серпні 2016 р.

Активність антиоксидантних ферментів (каталаза, гваякол- i бензидин-пероксидаза) вимірювали спектрофотометричними методами. Активність гваяколпероксидази (GPOD) оцінювали згідно 3 Ranieri et al. (2001) шляхом визначення окису гваяколу при 470 нм у реакційній суміші, яка містила оцтовий буфер (pH 6.0), 2 мМ гваяколу, 0,2 мл зразка і $0,15 \% \mathrm{H}_{2} \mathrm{O}_{2}$. Результати розраховували 3 урахуванням молярного коефіцієнта екстинкції і виражали в мМ гваякол/г сирої речовини (СР). Активність бензидин-пероксидази (BPOD) визначали на основі методу, запропонованого Gregory (1966). Зміни оптичної густини реєстрували за 1 хв при 470 нм після додавання $1 \% \mathrm{H}_{2} \mathrm{O}_{2}$ до реакційної суміші (оцтовий буфер, $\mathrm{pH}$ 6,0, 0,02 мМ бензидин і 0,2 мл зразка). Результат виражали в опт.од./Г СР. Активність каталази (САТ) оцінювали згідно 3 Goth (1991) шляхом вимірювання оптичної густини при 410 нм у реакційній суміші з 0,2 мл ферментного препарату, $0,1 \% \mathrm{H}_{2} \mathrm{O}_{2}$ i $4 \%$ молібдату амонію. Результати розраховували за калібрувальним графіком і виражали в мМ $\mathrm{H}_{2} \mathrm{O}_{2} / \Gamma$ хв. 
Повторність біохімічних досліджень 4-разова. Отримані дані оброблені статистично 3 використанням пакета Microsoft Statistica.

\section{Результати та їх обговорення}

У зв'язку із швидким розвитком промисловості, завантаженістю міського середовища автотранспортом у всьому світі посилюється антропогенний вплив, до якого рослини еволюційно не пристосовані. Ці негативні тенденції звужують межі толерантності рослин, зменшують їх стійкість до абіотичних i біотичних природних факторів (Lavrov et al., 2011). До цього ще додаються глобальні зміни клімату в бік його аридизації (Morgun et al., 2010; Lykholat et al., 2018). За таких умов у клітинах живих організмів розвиваються процеси окиснювального стресу 3 утворенням активних форм кисню (АФК), які мають високу реакційну здатність i порушують хід багатьох процесів у клітині, а також іiі структуру, викликають перекисне окиснення ліпідів, пошкоджують структурні білки, інгібують активність ензимів тощо (Quan et al., 2008; Gür et al., 2010). Ряд досліджень підтверджує, що в рослинах окиснювальний стрес виникає в результаті дії факторів різної природи (Gerosa et al., 2014; Lykholat et al., 2016). Антиоксиданти (AО) білкової природи в клітинах i тканинах рослин представлені супероксиддисмутазою, каталазою, пероксидазами, трансферазами, які, на відміну від низькомолекулярних речовин, характеризуються високою специфічністю дії, яка спрямована проти певних форм кисню.

Вивченню функціонального стану видів роду Amelanchier Medik. присвячено небагато робіт. Відомі роботи 3 дослідження видів ірги в умовах Північного i Правобережного Лісостепу, в яких дослідження були зосереджені в основному на вивченні вмісту вторинних метаболітів, таких як фенольні сполуки, аскорбінова кислота тощо (Andrienko, 2016; Strela, 1970). В умовах Степового Придніпров'я досліджено вміст проліну в листках представників роду Amelanchier Medik. Показано, що вони за рівнем проліну $є$ високоадаптованими до несприятливих посушливих умов Степу (Dolgova and Samojlova, 2010). Досліджено адаптивну здатність видів ірги в бруньках із залученням ферментів антиоксидантного захисту (Kabar et al., 2016).

Визначення активності ферментів антиоксидантного захисту в листках у різні фази вегетативного розвитку рослин дає уявлення про їх функціональний стан (Khromykh et al., 2016). Вивчені види характеризувалися високою активністю бензидин-пероксидази протягом всього весняно-літнього сезону порівняно 3 активністю GPOD і CAT (табл. 1).

\section{Таблиця 1}

Сезонна динаміка активності бензидин-пероксидази в листках видів ірги

\begin{tabular}{ccccc}
\hline \multirow{2}{*}{ Термін відбору зразківі } & \multicolumn{4}{c}{ Види роду Amelanchier Medik. } \\
\cline { 2 - 5 } & A. ovalis & A. canadensis & A. florida & A. spicata \\
\hline Квітень & $153,9 \pm 6,93$ & $158,8 \pm 5,56$ & $125,1 \pm 3,88$ & $145,2 \pm 5,08$ \\
Травень & $143,5 \pm 6,11$ & $39,5 \pm 1,14$ & $148,8 \pm 3,12$ & $98,9 \pm 2,37$ \\
Червень & $141,2 \pm 2,96$ & $54,4 \pm 1,42$ & $142,5 \pm 4,70$ & $119,2 \pm 2,15$ \\
Липень & $147,1 \pm 2,79$ & $192,9 \pm 5,21$ & $211,1 \pm 5,28$ & $172,5 \pm 2,93$ \\
Серпень & $173,2 \pm 4,80$ & $181,2 \pm 5,80$ & $189,7 \pm 3,42$ & $180,8 \pm 5,24$ \\
\hline
\end{tabular}

У листках A. ovalis активність BPOD за весь період спостереження виявилась високою і достатньо вирівняною, особливо в травні - липні. Найбільша активність ферменту відмічалась у серпні. Інші види, на відміну від A. ovalis, протягом періоду виявили більш різкі відміни в активності BPOD. Різниця була суттєвою, особливо у A. canadensis, у листках якого в травні та червні відмічалося різке падіння активності в 4,0 і 2,9 разу відповідно, порівняно $з$ квітнем, а в липні та вересні - різке підвищення, що свідчить про стресовий стан рослини.

Найвища активність BPOD зареєстрована у видів ірги канадської і рясноквітучої в липні, що пов'язано 3 несприятливим гідротермічним режимом у цей період. У виду A. spicata, як і у A. ovalis, пік активності припадав на серпень. У першого в липні спостерігалось зниження активності BPOD порівняно з квітнем на 18,8\%. Слід відзначити, що тільки у виду A. florida виявлене поступове підвищення активності бензидин-пероксидази від квітня до липня, а далі невелике зниження на 10,2 \%. Порівняно 3 квітнем у липні активність BPOD підвищувалась на 68,7 \% як реакція на посушливий період.

Порівняно з бензидин-пероксидазою набагато менше відомо про участь у забезпеченні термотолерантності рослин каталази і гваякол-пероксидази (Rusnak et al., 2013). GPOD бере участь в окисненні різних субстратів, таких як феноли, ароматичні аміни, а також у процесах лігніфікації. За результатами наших досліджень всі види виявилися подібними за напрямом змін активності гваякол-пероксидази. Відмінність полягала у величинах даного показника. Так, у листках A. ovalis i A. canadensis спостерігалась більш висока активність ферменту у квітні порівняно з A. spicata i A. florida (табл. 2).

Таблиця 2

Сезонна динаміка активності гваякол-пероксидази в листках видів ірги

\begin{tabular}{ccccc}
\hline \multirow{2}{*}{ Місяць відбору листків } & \multicolumn{4}{c}{ Види роду Amelanchier Medik. } \\
\cline { 2 - 5 } & A.ovalis & A. canadensis & A. florida & A. spicata \\
\hline Квітень & $77,5 \pm 2,31$ & $59,8 \pm 1,85$ & $31,4 \pm 0,78$ & $38,6 \pm 1,16$ \\
Травень & $9,10 \pm 0,23$ & $5,30 \pm 0,09$ & $8,80 \pm 0,25$ & $5,80 \pm 0,16$ \\
Червень & $14,0 \pm 0,47$ & $6,40 \pm 0,18$ & $16,5 \pm 0,51$ & $11,4 \pm 0,35$ \\
Липень & $5,46 \pm 0,15$ & $5,20 \pm 0,15$ & $11,2 \pm 0,34$ & $5,90 \pm 0,07$ \\
Серпень & $6,60 \pm 0,25$ & $10,9 \pm 0,28$ & $8,60 \pm 0,14$ & $7,21 \pm 0,22$ \\
\hline
\end{tabular}

Якщо у двох перших видів активність була на рівні 77,5 і 59,8 мкМ сек-1 г-1 СР, то в другій групі видів вона дорівнювала 31,4 і 38,6 мкМ сек-1 г-1 СР відповідно. Починаючи з травня (фаза активного росту і цвітіння) і до кінця періоду спостережень активність GPOD різко знижувалась у всіх видів ірги. Невелике зростання активності спостерігалося в червні, а саме у трьох видів A. ovalis, A. florida i A. spicata. У листках A. canadensis 
підвищення активності відмічено в серпні порівняно 3 періодом від травня до липня.

Активність каталази розглядається як індикатор функціонального стану рослин та їх реакції на впливи довкілля (Zajtseva, Dolgova, 2010). Аналіз динаміки активності каталази в листках представників роду Amelanchier Medik. показав подібність до такої у гваяколпероксидази: найвищий рівень спостерігався у квітні, а далі мало місце істотне гальмування активності ензиму (табл. 3).

\section{Таблиця 3}

Сезонна динаміка активності каталази в листках видів роду Amelanchier Medik.

\begin{tabular}{cccc}
\hline Місяць відбору & \multicolumn{3}{c}{ Види роду Amelanchier Medik. } \\
\cline { 2 - 4 } листків & A.ovalis & A. canadensis & A.florida \\
\hline Квітень & $37,9 \pm 0,45$ & $33,1 \pm 0,96$ & $13,8 \pm 0,21$ \\
Травень & $2,10 \pm 0,03$ & $3,20 \pm 0,10$ & $2,10 \pm 0,05$ \\
Червень & $0,34 \pm 0,01$ & $0,14 \pm 0,002$ & $0,36 \pm 0,007$ \\
Липень & $0,59 \pm 0,02$ & $0,97 \pm 0,03$ & $3,90 \pm 0,09 \pm 0,09$ \\
Серпень & $3,80 \pm 0,14$ & $4,90 \pm 0,06$ & $3,05 \pm 0,07$ \\
\hline
\end{tabular}

Динаміка активності каталази протягом вегетації виявилася найбільш подібною у видів A. ovalis i A. canadensis. У листках A. florida, на відміну від попередніх видів, відмічався невеликий пік активності в липні, а в серпні активність ферменту знижувалась на 21,8 \% порівняно $з$ липнем. Ірга колосиста (A. spicata) показала істотне підвищення активності САТ в 6,4 разу в серпні порівняно $з$ липнем.

Установлено видоспецифічність активності антиоксидантних ферментів, а також ізоферментного складу бензидин-пероксидази, що свідчило про різну ступінь адаптивності інтродукованих рослин до несприятливих зимових умов степової зони. Показано, що види A. florida i A. spicata виявились за цими показниками більш успішними в пристосуванні до умов зими. У той час як у видів A. ovalis i A. canadensis вплив несприятливих умов степової зони супроводжувався підвищенням активності антиоксидантних ферментів.

На основі отриманих нами результатів дослідження також показано доволі широкий діапазон міжвидової варіабельності активності ферменту в листках видів ірги, індукованих умовами навколишнього середовища. Це узгоджується з дослідженнями Zajtseva and Dolgova (2010), які вивчали динаміку активності пероксидази представників інших родових комплексів рослин в умовах Степової зони.

У ряді наукових робіт показано, що гваяколпероксидаза $\epsilon$ функціонально лабільним ферментом, який реагує на порушення клітинного гомеостазу за дії стресів, зокрема теплового, причому різні види рослин використовують різні механізми для запобігання пошкоджуючої дії стресів (Rusnak et al., 2008; Piryzhok et al., 2008). Так, у Arabidopsis thaliana індукція гваяколпероксидази спостерігалась на ранніх стадіях помірного теплового стресу, а в умовах жорсткого $\left(44{ }^{\circ} \mathrm{C}\right)$ - функція GPOD істотно знижувалась майже наполовину. У Zea mays помірний тепловий стрес не викликав істотних змін активності, у той час як тепловий шок зумовлював зростання активності GPOD на $60 \%$ (Piryzhok et al., 2008). У наших дослідженнях найвища активність спостерігалась на початку фази активного росту видів ірги, а за несприятливого температурного режиму вона була істотно знижена порівняно з початком спостереження на $93 \%$. Суттєва активація GPOD у квітні (фаза активного росту), на наш погляд, може бути пов'язана 3 процесами лігніфікації в більшій мірі, ніж із захистом від оксидативного стресу.

Таким чином, варіювання рівня активності антиоксидантних ензимів в листках ірги протягом вегетаційного періоду $€$ механізмом пристосування до умов довкілля і в цілому відображає адаптивну здатність досліджених видів, які мають високий антиоксидантний потенціал і можуть протистояти розвитку оксидативного стресу за певних впливів несприятливих абіотичних факторів.

\section{Висновки}

Результати досліджень дозволили з'ясувати значення змін основних показників системи антиоксидантного захисту, а саме ензимів - каталази, бензидин-пероксидази i гваякол-пероксидази, у листках представників роду Amelanchier Medik., інтродукованих у Степовому Придніпров'і, у процесі онтогенезу. Установлено, що кожний вид ірги має свій оптимум активності ферментів у різні періоди росту і розвитку рослин. Показано, що вивчені види мали найбільш високу антиоксидантну активність GPOD і CAT на початку фази активного росту рослин. У подальшому їх активність різко знижувалась і 3 травня по серпень залишалась стабільно низькою порівняно з квітнем у всіх видів ірги. На відміну від GPOD i CAT, зареєстровано високу активність бензидинпероксидази впродовж усього вегетаційного періоду. Максимум активності GPOD встановлений у фазу вторинного росту рослин за найбільш несприятливого гідротермічного режиму.

\section{References}

Alscher, R. G., Donahue, J. L, Cramer, C. L. (1997). Reactive Oxygen Species and Antioxidants: Relationships in Green Cells. Physiol. Plant, 100, 224-233.

Andrienko, O. D. (2016). Ekologo-biologichni osobly`vosti vy'div rodu Amelanchier Medik. v umovax introdukciyi u Pravoberezhnomu Lisostepu Ukrayiny [Ecological and biological peculiarities of species of Amelanchier Medik. genus in conditions of Pravoberezhnyi Forest-Steppe of Ukraine]. Avtoref. kand. biol. nauk. Uman (in Ukrainian).

Dolgova, D. G., Samojlova, M. V. (2010). Vmist prolinu yak pokazny`k stijkosti rosly`n-introducentiv rodu Amelanchier Medic. [The content of proline as parameter of stability of plant-introducents of Amelanchier Medic. genus.]. Zbirnyk naukovykh prats. ZNU, Zaporizhzhya, 29-32 (in Ukrainian).

Gerosa, G., Marzuoli, R., Finco, A., Monga, R., Fuzaro, L., Faoro, F. (2014). Contrasting effect of water salinity and ozone concentration on two cultivars of durum wheat (Triticum durum Desf.) in Mediterranean conditions. Environ. Poll., 193, 13-21.

Goth, L. (1991). A simple method for determination of serum catalase activity and revision of reference range. Clinica Chimica Acta, 196, 143-152.

Grebennikova, O. A. (2008). Osobennosti sostava i soderzhaniya fenolnih soedineniy $\mathrm{v}$ plodah alyichi [Peculirities of composition and content of phenolic compounds in fruit of cherry-plum]. Bulletin of the Nikitskiy bot. garden, 97, 66-68 (in Russian).

Gregory, R. P. F. (1966). A rapid assay for peroxidase activity. Biochem. J., 101(3), 582-583.

Gür, A., Demirel, U., Özden, M., Kahraman, A., Çopur, O. (2010). Diurnal gradual heat stress affects antioxidant 
enzymes, proline accumulation and some physiological components in cotton (Gossypium hirsutum L.). African J. of biotech., 9(7), 1008-1015.

Kabar, A., Khromykh, N., Shupranova, L., Lykholat, Y. (2016). Antioxidant enzymes and peroxidase isoforms variation in the dormant buds of fruit plants introduced in the Steppe zone. Agrobiodiversity for improving nutrition, health and the life quality. Nitra, 155-159.

Khromykh, N. O., Lykholat, Y. V., Kovalenko, I. M., Kabar, A. M., Didur, O. O., Nedzvetska, M. I. (2018). Variability of the antioxidant properties of Berberis fruits depending on the plant species and conditions of habitat. Regul. Mech. Biosyst., 9(1), 56-61.

Kuklina, A. G. (2011). Naturalization of Amelanchier Medik. species from North America in a secondary habitat. Russian J. of Biol. Invasions, 2(2-3), 103-107.

Kuklina, A. G., Sorokopudov, V. N., Tsybulko, N. C. (2017a). Fitohimicheskiy analyz plodov i listev irgi (Amelanchier Medik.) $\mathrm{v}$ kultigennih i invasionnih populyatsiyah [Phytochemical analysis of fruits and leaves of Saskatoon (Amelanchier Medik.) in cultigenic and invasiones populations]. Plodovodstvo and yagodovodstvo of Russia, 49, 39-42 (in Russian).

Kuklina, A., Sorokopudov, V., Stepanova, A. (2017). Amelanchier Medik. (Rosaceae) fruits - a nutrition dietary product and a source material for phytopharmacology. Agrobiodiversity, 268-272.

Lavrov, V. V., Blinkova, O. I., Ivanenko, O. M., Polyschuk, Z. V. (2017). Zmini konsortivnih zvyazkiv afiloforoyidnih gribiv ta Quercus robur L. u rekreatsiyno-ozdorovchih lisah zelenoyi zoni m. Umani [Changes in consortial links of Aphyllophoroid fungi and Quercus robur L. in the recreational forests of the green zone of the city]. Ecology and Noospherology, 28(3-4), 5-20 (in Ukrainian).

Lykholat, Y. V., Khromikh, N. O., Shupranova, L. V., Kovalenko, I. M, Fedenko, V. S., Alekseeva, A. A. (2018). Zakonomirnosti adaptatsiyi aborigennih ta introdukovanih vidiv derevnih roslin do minlivih umov stepovogo Pridniprov'ya: monografiya [Conformities to law of adaptation of aborigines and introductivenes species of woody plants to the changeable terms of Pridniprov'je steppe: monograph]. FOP Tzema S.P., Sumy (in Ukrainian).

Morgun, V. V., Kirizij, D. A., Shadchina, T. M. (2010). Ekofiziologicheskie i geneticheskie aspektyi adaptatsii kulturnyih rasteniy $\mathrm{k}$ globalnyim izmeneniyam klimata [Ecophysiological and genetic aspects of adaptation of cultural plants to the global changes of climate].
Physiology and biochemistry of cult. plants, 42(1), 3-22 (in Russian).

Polonska, A. K., Ejov, V. N., Korniljev, G. V., Grebennikova, O. A. (2007). Biologicheski aktivnyie veschestva listev nekotoryih plodovyih kultur $\mathrm{v}$ svyazi s perspektivoy ih ispolzovaniya $\mathrm{v}$ pischevyih produktah [Bioactiv substances of leaves of some fruit cultures in connection with prospect of their us in food products]. Uchenyie zapisky TNU imeni V.I. Vernadskogo, series Biology, Chemistry, 20(3), 122-127 (in Russian)

Prisedsky, Y., Kabar, A., Lykholat, Y., Martynova, N., Shupranova, L. (2017). Activity and isoenzyme composition of peroxidase in Japanese quince vegetative organs under steppe zone conditions. Biologija. (Lietuvos mokslu academia), 63(2), 185-192.

Pyryzhok, R. Y., Volkov, R. A., Panchuk, I. I. (2008). Aktivnist peroxidasi prorostkiv kukurudzi $\mathrm{v}$ umovah teplovogo stresu [Activity of peroxidase of mays seedlingsupon heat stress treatment]. Physiol. and biochem. of cult. plants, 40(1), 1-6 (in Ukranian).

Pyryzhok, R. Y., Volkov, R. A., Panchuk, I. I. (2008). Temperaturozalezhna aktivnist gvajakolperoxidasi u APX2 nokaut-mutantiv arabidopsisu [Temperature-dependent activity of guaiacolperoxidase in APX2 nokaut-mutants of arabidopsis]. The bulletin of the Ukrainian society of genetics and selectors, 6(2), 275-281 (in Ukranian).

Quan, L. J., Zhang, B., Shi, W. W., Li, H. Y. (2008). Hydrigen peroxide in plants: a versatile molecule of the reactive oxygen species network. J. Integr. Plant Biol., 50(1), 2-18.

Ranieri, A., Castagna, A., Baldam, B., Soldatini, G. F. (2001). Iron deficiency differently affects peroxidase isoforms in sunflower. J. Exp. Bot., 52(354), 25-35.

Rusnak, T. O., Doliba, I. M., Volkov, R. A., Panchuk, I. I. (2013). Aktivnost gvajakolperoxidasi u nokautnoj linii KOCat2 Arabidopsis thaliana za umov teplovogo stresu [Guaiacol peroxidase activity in Cat2 Knock-out mutant of Arabidopsis thaliana upon heat stress treatment]. Physiol. and biochem. of cult. plants, 45(3), 19-26 (in Ukranian).

Strela, T. E. (1970). Biologicheskie osobennosti vidov roda irga (Amelanchier Medic,) i percpektivi ih ispolzovania [Biological perticulirties of irga kinds (Amelanchier Medic,) and prospects of their use]. Avtoref. dissert. Kiev (in Russian).

Zajtseva, I. O., Dolgova, L. G. (2010). Fiziologo-biohimichni osnovi introduktsii derevnih roslin u stepovomu Pridniprovji: monografia [Physiological and biochemical basis of introduction in Steppe Pridneprov'e]. Publ. house of Dnipropetrovsk National University, Dnipropetrovsk (in Ukrainian) 